\title{
AN EXAMPLE OF MIGMATITE ORIGIN BY DEHYDRATING METAMORPHISM
}

\author{
EVA FEDIUKOVÁ and MILOŠ SUK
}

\begin{abstract}
FEDIUKOVÁ, EVA and SUK, MILOŠ 1979: An example of migmatite origin by dehydrating metamorphism. Bull. Geol. Soc. Finland 51, $1-9$.

An unusual type of garnetiferous migmatite has been studied at Tábor (Moldanubicum of southern Bohemia) characterized by a coarse patchy quartzo-felspathic neosome with conspicuously large garnet crystals and a biotite paragneiss paleosome. The neosome is very different in textural and mineralogical appearance from the paleosome. Nevertheless, the chemical compositions of both migmatite components are very similar except for the contents of water, manganese, iron, and some trace elements. This indicates that the migmatite was formed in a process of metamorphic recrystallization from a previously homogeneous biotite paragneiss. Variation in water pressure during recrystallization (migmatization) under the conditions of lowpressure and high-temperature metamorphism is probably responsible for the mineralogical differences between the neosome and the paleosome.
\end{abstract}

Eva Fediuková and Miloš Suk, Geological Survey of Czechoslovakia, Hradební 9, 11015 Prague 1, Czechoslovakia.

\section{Introduction}

In his publication on migmatites Mehnert (1968) summarized the basic principles of the formation of migmatites, i.e. mechanical injection of magmatic melt, metasomatic exchange of substances and anatectic differentiation.

One of the most important ways of establishing the origin of migmatites is to compare the chemical compositions of the paleosome and neosome. ${ }^{1}$ This can only be done, however, if both migmatite components - paleosome and neosome - can be easily separated. The garnet migmatite of Tábor is particularly suitable for such a study (Fig. 1).

1 Designation used according to Mehnert (1968).

\section{Geological setting and composition of the rock}

The garnetiferous migmatite is located in the town of Tábor (southern Bohemia), on the right bank of the Lužnice River. The outcrop has been described in detail by Čech (1965). The rock forms a body about $80 \mathrm{~m}$ long and $15 \mathrm{~m}$ thick within the paragneisses of the Moldanubian Varied Group, at the contact of the Central Bohemian Pluton. The Pluton in that area is a biotite-hornblendepyroxene syenite (Fig. 2). The sample studied is a stromatite-merismite migmatite (agmatite) composed mainly of dark-coloured portions of the paleosome and of lightcoloured portions of neosome. The dark coloured biotitic portions of the paleosome 


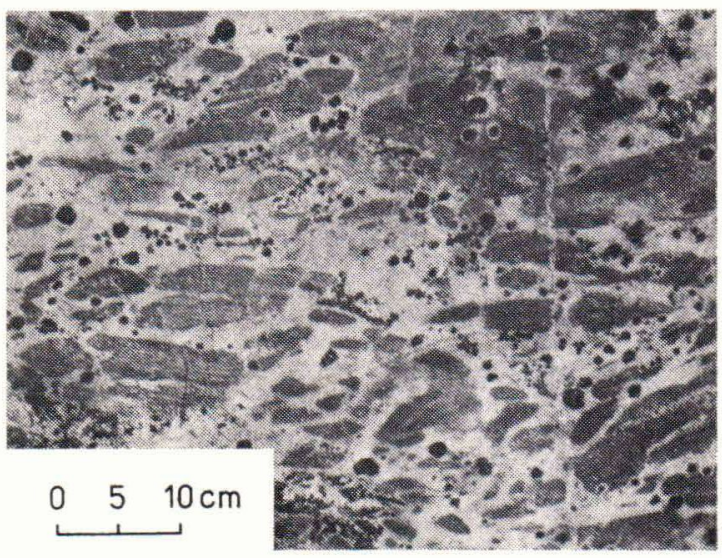

Fig. 1. Distribution of paleosome and neosome in garnetiferous migmatite. (andesine), microcline and rare sillimanite. The neosome is a rock of granitic character with large garnet porphyroblasts set in a groundmass of microcline, plagioclase (oligoclase), quartz and rare biotite and muscovite flakes.

The garnets are dark reddish-brown and rounded crystals, up to $2 \mathrm{~cm}$ in size. They are randomly fractured and show biotite along the fractures. Light-coloured feldspar rims envelop the garnet grains (see the left upper part of Fig. 1). Nováček (1932) identified the garnet as almandine $(75.29 \%$ almandine, $8.29 \%$ spessartine, $8.36 \%$ pyrope, $8.06 \%$ grossularite). Table 1 gives the results of electron-microprobe analyses of the garnet are of irregular and diffuse schlieren-like *and biotite. Garnets show compositional shape. The paleosome corresponds to finegrained biotite gneiss with plagioclase zoning with cores enriched in iron and manganese and rims richer in magnesium and

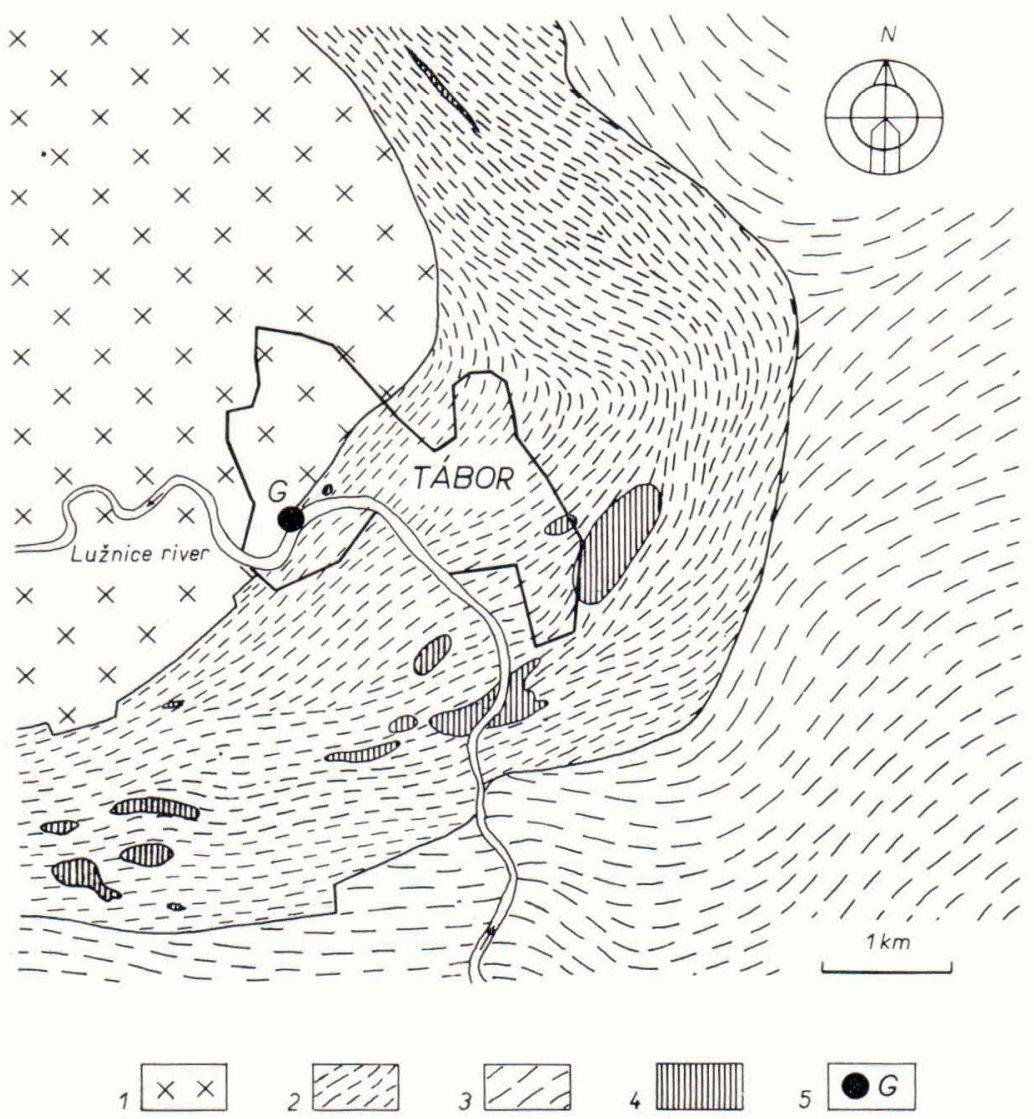

Fig. 2. Geological setting of the locality. Simplified from Cech (1965). 1 - Tábor syenite, 2 - Varied Group of the Moldanubicum (paragneiss and migmatite with quartzite, amphibolite and erlan interlayers), 3 Monotonous Group of the Moldanubicum (biotite and sillimanite-biotite paragneiss), 4 - orthogneiss, 5 - location of garnetiferous migmatite. 
Table 1. Analyses of garnet and biotite from the migmatite.

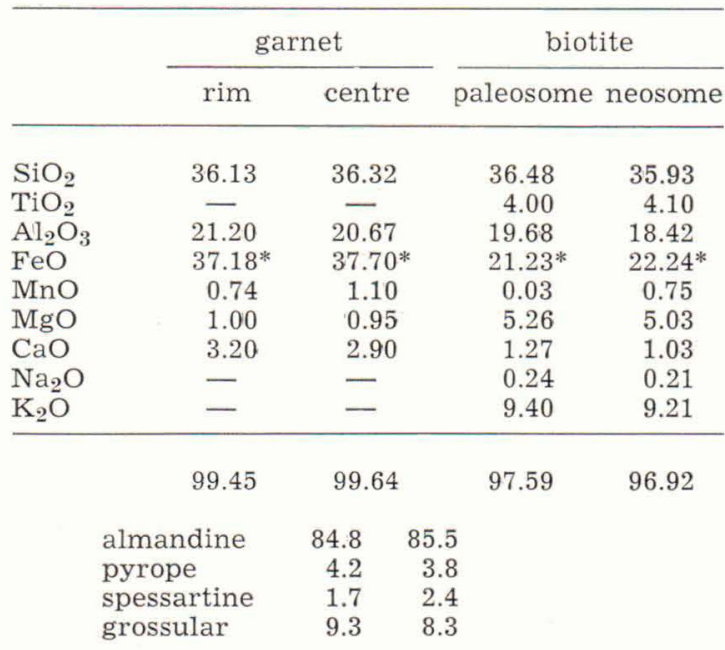

* Total iron recalculated to ferrous iron.

Analyses were performed by an ARL-EMX microprobe. Natural garnets and biotites were used as standards. The results are the averages of 4 analyses of biotite and 6 analyses of garnet.

calcium (Fediuková 1973). The formation of garnet reflects a decrease in the water content of the rock, a process that took place mainly at the expense of biotite in a manner similar to the formation of cordierite in other Moldanubian migmatites (Suk 1964). Symplectites of biotite and quartz were formed at the expense of the garnet during the last retrogressive stage of metamorphic development.

The chemical compositions of the biotites in the paleosome and the neosome are nearly identical. The biotite of the paleosome is altered in places. Only reddish-brown fresh biotites were compared. Flakes of the green altered secondary biotite contain less $\mathrm{Ti}$ and $\mathrm{K}$ and more $\mathrm{Fe}$ than the reddish-brown biotite.

Plagioclase, which is often altered, occurs in rather small amounts. It is more calcic in the paleosome, where it averages andesine

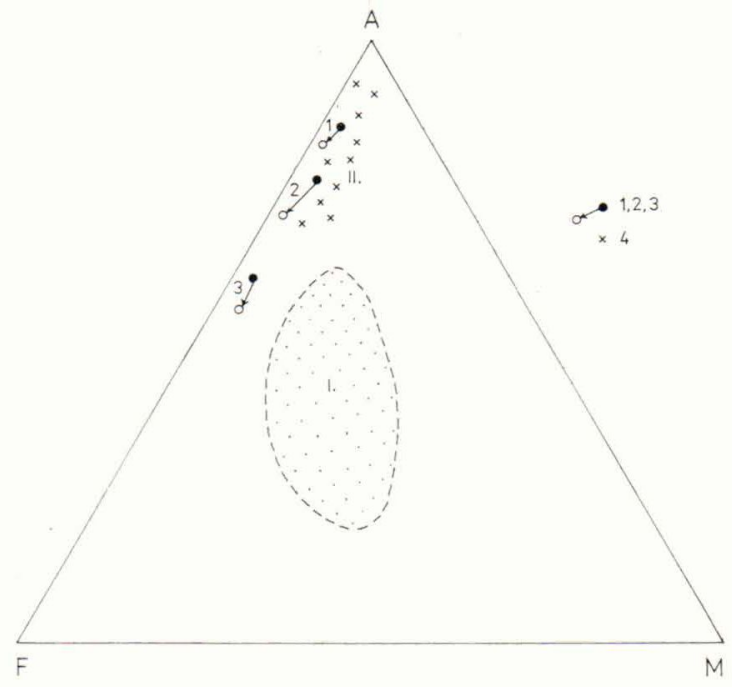

Fig. 3. AFM diagram of Moldanubian gneisses and migmatites. Stippled - field of paragneisses in Central Bohemia and in Bavaria after M. Suk 1964 and P. Blümel-W. Schreyer 1977.

$1,2,3$ - projection points of garnetiferous migmatite (full circles $=$ paleosome, open circles $=$ neosome). 4 - projection points of the Moldanubian leucocratic gneisses (metavolcanites) after Dudek et al. 1974.

in composition. The plagioclase in the neosome is oligoclase. K-feldspar (microclineperthite) is the predominant light mineral in the neosome; its abundance in the paleosome is small.

In the bulk composition, the rock is identical to some special types of leucocratic metamorphic rocks of the Moldanubicum (see Fig. 3 ). These rocks occur in concordant layers in the Varied Group and are marked by their high potassium content. According to Dudek et al. (1974), these rocks correspond to metamorphosed trachytic tuff. The locality studied is apparently situated in the extension of a layer of this metamorphosed tuff in the zone of migmatization at the contact with the Central Bohemian Pluton.

Not only the mineralogical composition but also the structure of the original gneiss is preserved in the paleosome (Fig. 4). Moreover, some individual parts of the paleosome 


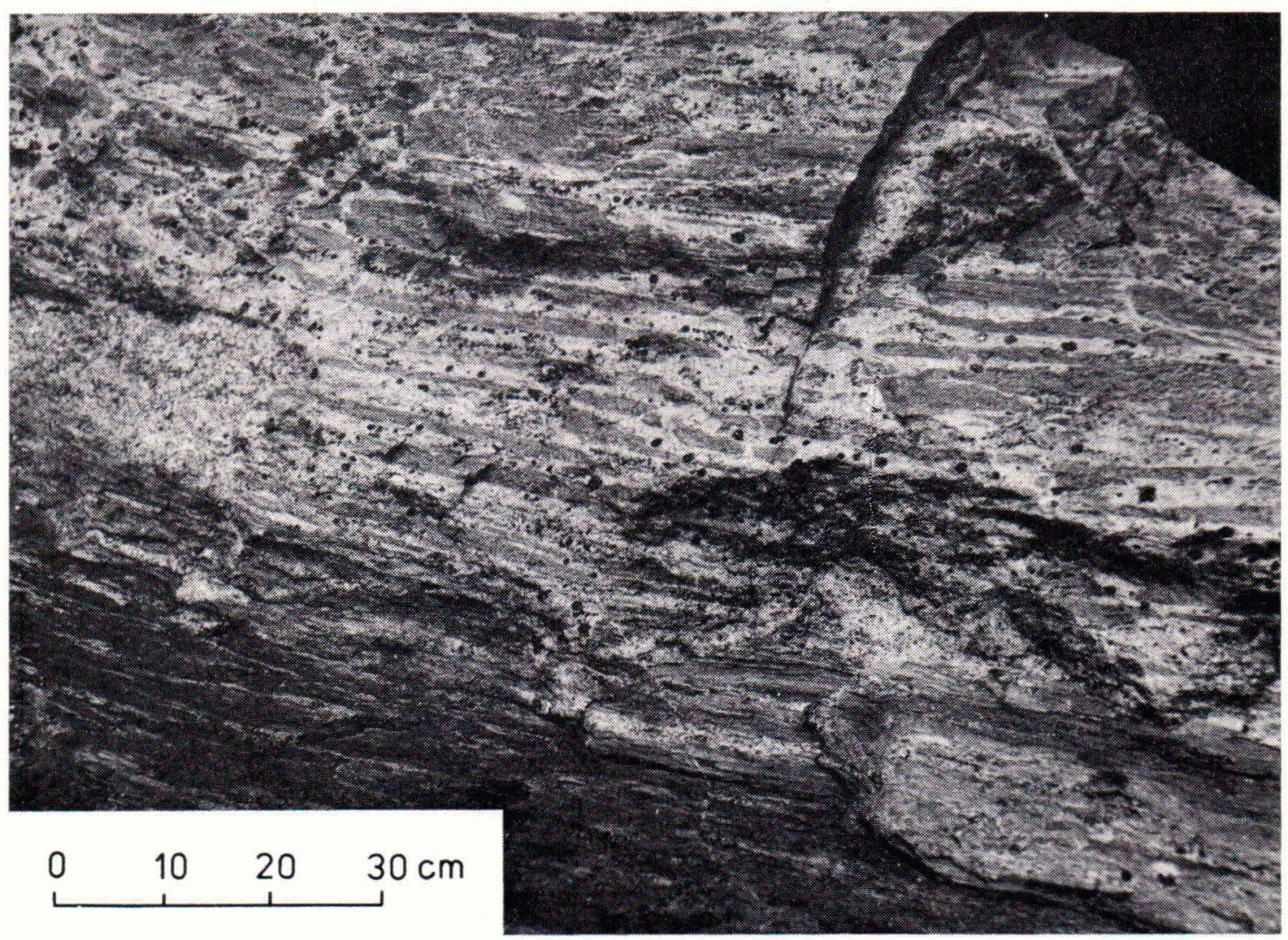

Fig. 4. Garnetiferous migmatite from Tábor. Preserved parallel structure of the paleosome and neosome.

observed in the migmatite still exhibit their original geometric positions in space (Fig. 4), which precludes magma injection as the origin of the migmatite. The neosome forms streaks oriented mainly along the primary foliation planes and along the cross joints. Some isolated rounded portions of the neosome, one centimetre in size have often developed in the paleosome and given rise to a biotite-free plagioclase and quartz rim around garnet grains. This implies that the neosome was formed at the expense of the paleosome during the crystallization of the garnet. Macroscopically, the boundary between both components of the migmatite is sharp and without any transition. Only under the microscope is it seen that the minerals grow from the neosome towards the paleosome.

\section{Petrochemistry}

Three rock samples were taken from different localities of the rock, and their neosome and paleosome were analysed separately (Table 2). The computed ACF and A'KF values are given in Fig. 5 .

The analytical results and calculations show that, in chemical composition the neosome corresponds to the paleosome, but that in mineral composition they differ significantly. The two rock components also correspond to the same metamorphic facies. 
Table 2. Analyses of the garnetiferous migmatite from Tábor.

\begin{tabular}{|c|c|c|c|c|}
\hline & \multicolumn{3}{|c|}{$\mathrm{Neosome}$} & \multirow[b]{2}{*}{ averages } \\
\hline & M 1 & M 2 & M 3 & \\
\hline $\mathrm{SiO}_{2}$ & 57.24 & 59.98 & 62.31 & 59.84 \\
\hline $\mathrm{TiO}_{2}$ & 0.04 & 0.32 & 0.18 & 0.18 \\
\hline $\mathrm{Al}_{2} \mathrm{O}_{3}$ & 18.95 & 18.73 & 18.39 & 18.69 \\
\hline $\mathrm{Fe}_{2} \mathrm{O}_{3}$ & 0.75 & 1.23 & tr. & 0.66 \\
\hline $\mathrm{FeO}$ & 7.48 & 4.13 & 2.64 & 4.75 \\
\hline $\mathrm{MnO}$ & 0.14 & 0.11 & 0.05 & 0.10 \\
\hline $\mathrm{MgO}$ & 0.64 & 0.45 & 0.28 & 0.46 \\
\hline $\mathrm{CaO}$ & 1.93 & 0.55 & 0.46 & 0.98 \\
\hline $\mathrm{Li}_{2} \mathrm{O}$ & tr. & 0.01 & 0.004 & tr. \\
\hline $\mathrm{Na}_{9} \mathrm{O}$ & 1.60 & 1.96 & 2.06 & 1.87 \\
\hline $\mathrm{K}_{2} \mathrm{O}$ & 9.60 & 11.67 & 12.60 & 11.29 \\
\hline $\mathrm{P}_{2} \mathrm{O}_{5}$ & 0.38 & 0.11 & 0.12 & 0.20 \\
\hline $\mathrm{CO}_{2}$ & 0.26 & 0.17 & 0.03 & 0.15 \\
\hline $\mathrm{H}_{2} \mathrm{O}+$ & 0.47 & 0.54 & 0.40 & 0.47 \\
\hline $\mathrm{H}_{2} \mathrm{O}-$ & 0.06 & 0.03 & 0.18 & 0.09 \\
\hline $\mathrm{S}$ & tr. & 0.02 & 0.01 & 0.01 \\
\hline \multirow[t]{2}{*}{$\mathrm{C}$} & - & - & 0.03 & 0.01 \\
\hline & 99.5 & 100.01 & 99.74 & 99.75 \\
\hline
\end{tabular}

Gamma-ray spectrometric determinations

\begin{tabular}{llll}
\hline & U ppm & Ra ppm & Th ppm \\
\hline Paleosome & 2.0 & 4.8 & 23.8 \\
Neosome & 5.7 & 4.1 & 30.2 \\
\hline
\end{tabular}

\begin{tabular}{|c|c|c|c|c|}
\hline & \multicolumn{3}{|c|}{ Paleosome } & \multirow[b]{2}{*}{ averages } \\
\hline & S 1 & S 2 & S 3 & \\
\hline $\mathrm{SiO}_{2}$ & 56.84 & 60.55 & 62.18 & 59.86 \\
\hline $\mathrm{TiO}_{2}$ & 0.04 & 0.46 & 0.42 & 0.31 \\
\hline $\mathrm{Al}_{2} \mathrm{O}_{3}$ & 20.18 & 18.72 & 18.44 & 19.11 \\
\hline $\mathrm{Fe}_{2} \mathrm{O}_{3}$ & 1.23 & 0.64 & 0.33 & 0.73 \\
\hline $\mathrm{FeO}$ & 5.93 & 2.69 & 1.68 & 3.43 \\
\hline $\mathrm{MnO}$ & 0.03 & 0.01 & 0.01 & 0.02 \\
\hline $\mathrm{MgO}$ & 0.50 & 0.60 & 0.51 & 0.54 \\
\hline $\mathrm{CaO}$ & 1.37 & 0.43 & 0.41 & 0.74 \\
\hline $\mathrm{Li}_{2} \mathrm{O}$ & tr. & 0.02 & 0.009 & tr. \\
\hline $\mathrm{Na}_{2} \mathrm{O}$ & 1.72 & 2.02 & 2.10 & 1.95 \\
\hline $\mathrm{K}_{2} \mathrm{O}$ & 10.28 & 11.47 & 13.00 & 11.58 \\
\hline $\mathrm{P}_{2} \mathrm{O}_{5}$ & 0.14 & 0.16 & 0.13 & 0.14 \\
\hline $\mathrm{CO}_{2}$ & 0.13 & 0.14 & 0.02 & 0.10 \\
\hline $\mathrm{H}_{2} \mathrm{O}+$ & 0.75 & 1.32 & 0.74 & 0.94 \\
\hline $\mathrm{H}_{2} \mathrm{O}-$ & 0.19 & 0.07 & 0.18 & 0.15 \\
\hline $\mathrm{F}$ & - & 0.032 & - & tr. \\
\hline $\mathrm{S}$ & - & tr. & - & tr. \\
\hline $\mathrm{C}$ & - & - & 0.04 & 0.01 \\
\hline & 99.33 & 99.33 & 100.19 & 99.61 \\
\hline
\end{tabular}

Analyses IM 1, S 1 - D. Kučerová (1969), IM 2, S 2, - V. Novotný (1972), M 3, S 3 - M. Huka (1974), Geological Survey, Prague.

Gamma-ray spectrometric determination - Laboratory, Uranium Mines, Přibram, 1972.

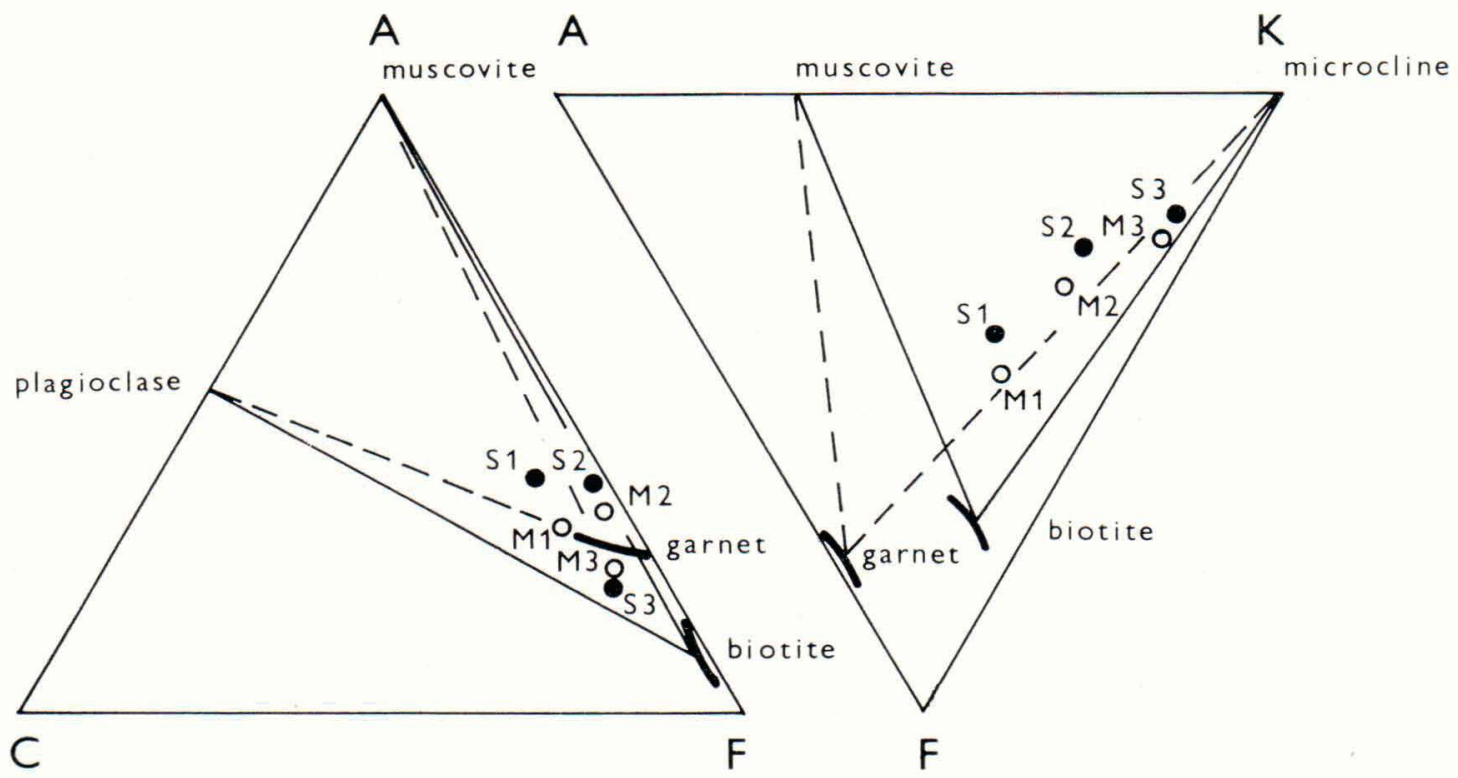

Fig. 5. ACF and A'KF diagrams for the components of the migmatite. M 1, M 2, M 3 - projection points of neosome, S 1, S 2, S 3 - projection points of paleosome. 


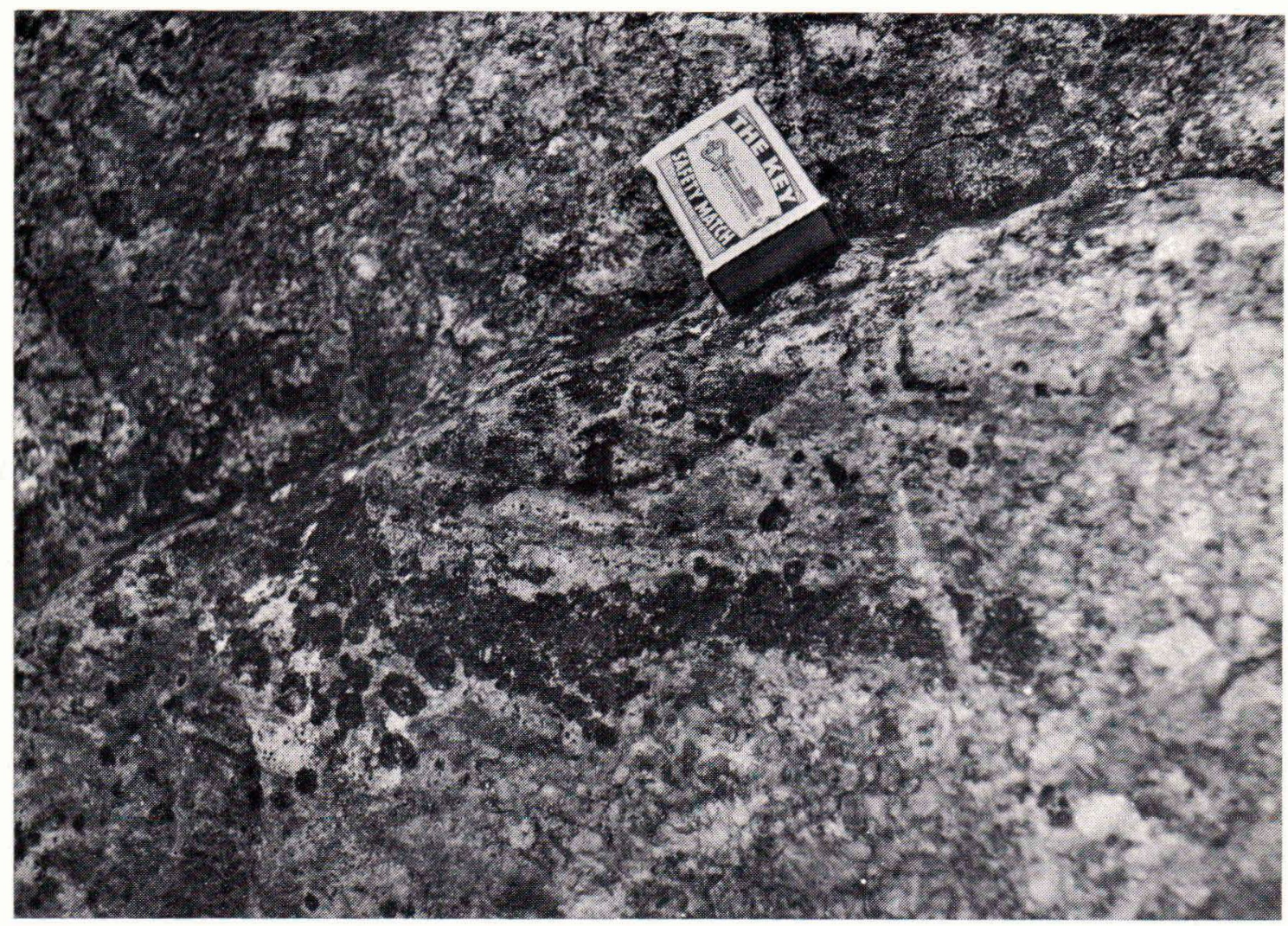

Fig. 6. Garnetiferous migmatite from Tábor. Local concentration of garnet crystals in the neosome.

No appreciable difference has been found in the contents of the essential major oxides, $\mathrm{SiO}_{2}, \mathrm{CaO}, \mathrm{Na}_{2} \mathrm{O}$ and $\mathrm{K}_{2} \mathrm{O}$. The chemical analyses of the neosome and paleosome are very similar. The neosome is relatively enriched in manganese, probably owing to the strong affinity of Mn to the garnet structure. The concentration of manganese in the growing garnet was presumably brought about by diffusion in a way comparable to the concretionary growth of garnet porphyroblasts in crystalline schists. The enrichment of the neosome in iron is probably due to irregular distribution of the garnet nucleii (as is shown on Fig. 6) which can cause local accumulations of crystals. This local accumulation of garnets is also reflected in the variation in the neosome analytical data. The removal of part of the uranium and thorium (Table 2) released from the biotite and accessory minerals (mainly monazite) in the paleosome is related to the migration of volatiles during recrystallization. The compositional differences between the neosome and the paleosome are less significant than the differences among individual samples of the paleosome and the neosome and correspond to the migration range during the recrystallization period.

The main difference that developed during the migration of the material is due to content of the volatile components. This is especially so for the water content, which, according to the analytical data is about 50 per cent lower in the neosome than in the paleosome. 


\section{Discussion}

Examples of migmatite origin attributed to magma injection, metasomatic import of alkalies and other granitic material, or partial anatexis have been described from the classical region of Southern Finland (P. Eskola, 1933, 1961; A. Simonen, 1948; M. Härme 1958, 1959, 1962). Extensive migration of the material has been proved in all the examples quoted. Härme supposed that microcline originated at the expense of plagioclase with a contemporaneous release of $\mathrm{Al}_{2} \mathrm{O}_{3}$ that gave rise to sillimanite, cordierite and almandine. However, some potassium, which is reflected in the biotitization of the amphibole must have been imported because the original rock was poor in this element.

The results of the study of the garnetiferous migmatite from Tábor suggest that

a) the formation of migmatite does not involve any major addition or subtraction of material even though the paleosome and the neosome are quite different in appearance

b) the paleosome and the neosome have similar chemical compositions, the main exception being the water content. There are small differences in the content of some other elements (Fe, Mn, Th, U)

c) relative to the paleosome the neosome is depleted in water by about 50 per cent.

It is suggested that no injection of magma or external metasomatic processes took place during the formation of the migmatite. The similar compositions of the paleosome and the neosome exclude an origin through anatectic differentiation or through partial melting. The bulk compositions of both components correspond to the bulk compositions of unmigmatized equivalents of this rock and both tend to have a magmatic composition. This is consistent with the interpretation that they derived from trachytic rocks by metamorphism.
Chemistry and texture enable the formation of the garnet migmatite of Tábor to be interpreted only in terms of differential recrystallization of a homogeneous rock as a result of heating produced by the adjacent Central Bohemian Pluton. Water escaped from the heated rock along the joints and schistosity planes (Fig. 7). Hydrous minerals, mainly biotite, were decomposed in the dehydrated rock and water-free minerals, garnets and feldspars, formed at the expense of the primary micas. During this process a relative movement of some elements took place. No essential mineral reconstruction occurred in the parts where the water content remained unchanged. The original rock was thus divided into two components: a gneiss paleosome and a feldspar-rich neosome. The recrystallization can be expressed by the following scheme:

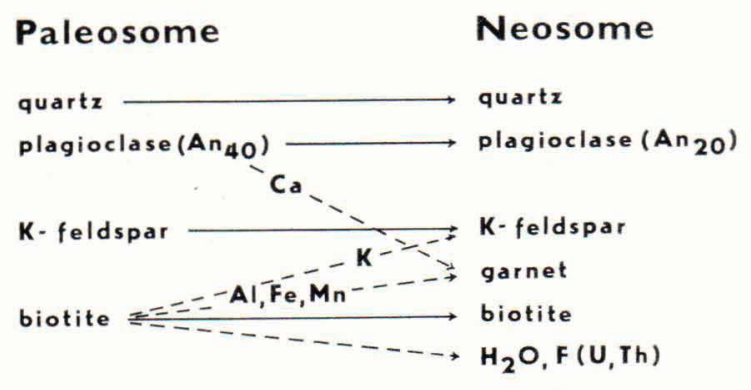

Many other Moldanubian phlebite-stromatite migmatites with cordierite, whose chemical composition does not differ from that of non-migmatized paragneisses (Suk 1964, Krupička 1968), may have been formed in a similar process. In the course of migmatization, these rocks were also depleted in water, $\mathrm{F}, \mathrm{Ar}, \mathrm{Au}, \mathrm{Pb}$ and radioactive elements. Depletion in $\mathrm{H}_{2} \mathrm{O}$ can be estimated to have been by about $50 \%$ of the original amount (Matolín 1970, Suk 1972). The average MnO content in the specimen of biotite paragneiss and migmatites is $0.10 \%$, whereas garnetiferous varieties of these rocks are enriched 


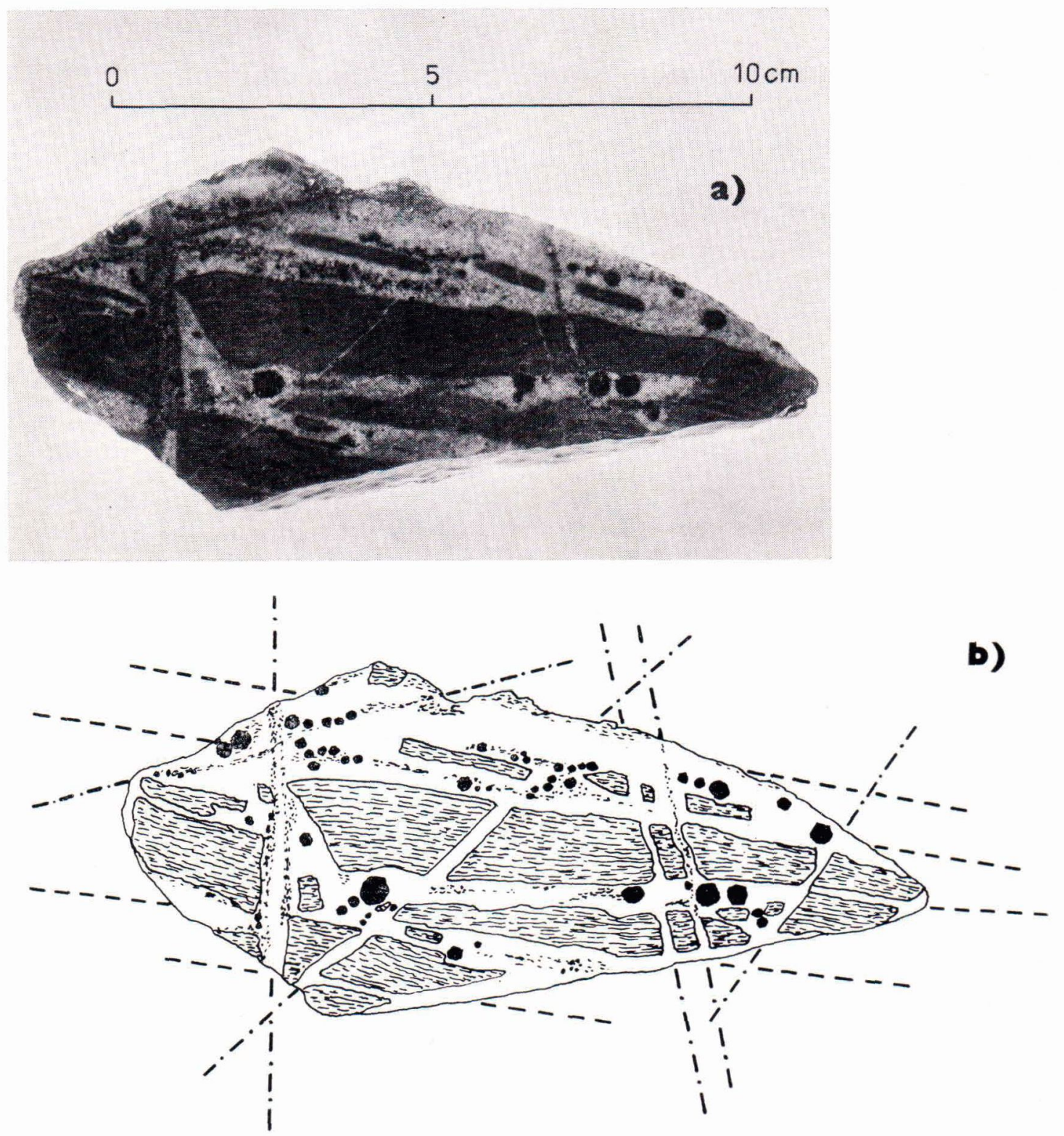

Fig. 7. Formation of dehydrated parts in the garnetiferous migmatite. a - macrophotograph, b scheme showing zones of dehydration following the fracture pattern. Dashed lines-foliation planes, dotand-dash lines - oblique fractures.

in manganese; their average content of $\mathrm{MnO}$ is $0.30 \%$. High values up to $\mathrm{MnO} 0.60 \%$ have been recorded exceptionally. Changes in the total iron content have not been noted. In contrast to the migmatite studied in the present context, the content of $\mathrm{Fe}_{2} \mathrm{O}_{3}$ in the rocks described above was markedly increased during the migmatization process and led to the formation of magnetite. The structure of those rocks, however, does 
not allow the composition of the two components to be assessed separately, rather the above scheme for the origin of anhydrous minerals at the expense of micas (formation of cordierite and $\mathrm{K}$-feldspar) is also valid for these migmatites. In any case, the possibility of migmatite being produced by differential dehydrating metamorphism must be taken into account.

Obviously this process can only have taken place if the leucocratic component of the migmatite is

a) of the same composition b) more anhydrous than the paleosome

c) if the contents of the recrystallized minerals are proportional to the paleosome composition (e.g. the magnetite content in the cordierite-K-feldspar migmatite is proportional to the quantity of altered biotite)

d) the textural evidence of the minerals indicates that anhydrous minerals originated at the expense of those richer in water (e.g. the occurrence of bleached halos rimming garnets).

\section{REFERENCES}

Blümel, P. and Schreyer, W. (1977) Phase Relations in Pelitic and Psammitic Gneisses of the Sillimanite-Potash Feldspar and Cordierite-Potash Feldspar Zones in the Moldanubicum of the Lam-Bodenmais Area, Bavaria. J. Petrol. 18 (3), 431-459.

Čech, V. (1965) Příspěvek ke geologii a petrografii táborského syenitového masivu. Čas. Mineral. Geol. 9, 291-299.

Dudek, A., Matějovská, O. and Suk, M. (1974) Orthogneisses of the Gföhl type in BohemianMoravian Moldanubicum. Krystalinikum 10, $67-78$.

Eskola, P. (1933) On the differential anatexis of rocks. Bull. Comm. Géol. Finlande 103, 12-25.

- (1961) Granitization of quartzose rocks. Bull. Comm. Géol. Finlande 196, 483-498.

Fediuková, E. (1973) Zoning of garnets in the rocks from the Moldanubicum. Sbor. geol. Věd, G 24, $7-72$.

Härme, M. (1958) Examples of the granitization of plutonic rocks. Comptes Rendus Soc. Géol. Finlande 183, 45-64.

- (1959) Examples of the granitization of gneisses. Comptes Rendus Soc. Géol. Finlande 184, 4358.
- (1962) Examples of anatexis. Comptes Rendus Soc. Géol. Finlande 187, 113-125.

Krupička, J. (1968) Sharp Boundaries in Crystalline Rocks and Their Interpretation. Int. Geol. Congr., 23rd Session, Czechoslovakia 4, 43-59.

Matolín, M. (1970) Radioaktivita hornin Českého masivu. Knihovna ÜÜG 41, 1-97.

Mehnert, K. R. (1968) Migmatites and the Origin of Granitic Rocks. Amsterdam-London-New York, Elsevier.

Nováček, R. (1932) Granáty československých pegmatitu. Věst. Král. čes. Společ. Nauk, 1-52.

Simonen, A. (1948) On the petrology of the Aulanka area in south-western Finlande. Bull. Comm. Géol. Finlande 143, 1-66.

Suk, M. (1964) Material Characteristics of the Metamorphism and Migmatization of Moldanubian Paragneisses in Central Bohemia. Krystalinikum 2, 71-105.

- (1972) Origin of Migmatites of the South Bohemian Moldanubicum by Regional Low-Pressure Metamorphism. Int. Geol. Congr. 24th, Montreal, Sect. 2, 114-121.

Manuscript received, October 3, 1978 